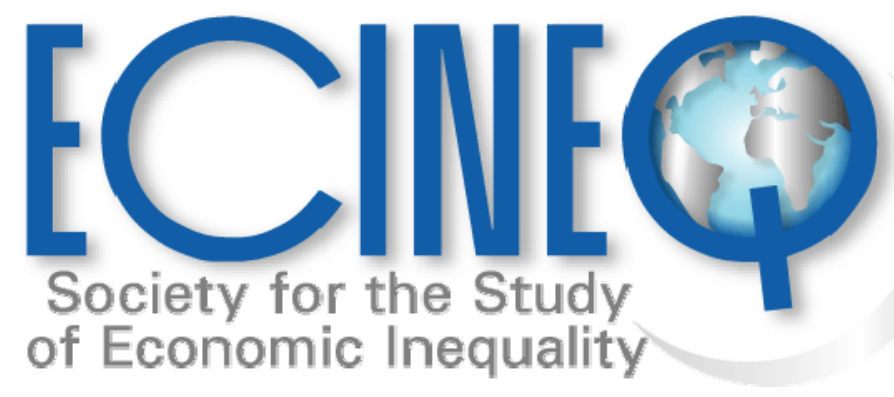

Working Paper Series

Can the longevity risk alleviate The annuitization puzzle?

Empirical evidence from Dutch data

Federica Teppa 


\title{
Can the longevity risk alleviate The annuitization puzzle? Empirical evidence from Dutch data*
}

\author{
Federica Teppa ${ }^{\dagger}$ \\ De Nederlandsche Bank (DNB) and Netspar
}

\begin{abstract}
This paper provides new evidence on individual preferences over annuities and lump sum payments based on hypothetical questions posed in the DNB Household Survey in 2005. Contrary to the majority of papers in the annuitization puzzle literature, this study allows to control explicitly for the subjective survival probability (SSP), a key driver of the decision about whether to annuitize or not as a perceived measure of longevity risk. We find that people expecting to live longer do claim to prefer the annuity. This finding is very robust to controlling for bequest motives. The relevance of this paper is twofold. First, it delivers an important empirical result on the role of the SSP that is still not directly tested in the literature. Second and more important, combined with the empirical evidence that on average individuals tend to systematically underestimate their life expectancy, the findings have strong policy implications. The annuitization puzzle may be alleviated by helping individuals in better assessing their longevity risk, rather than forcing their actions.
\end{abstract}

Keywords: Longevity Risk; Annuitization Puzzle; Survey Data; Hypothetical Choices JEL classification: C5; C8; D12; G11

\footnotetext{
* We thank Maarten van Rooij for providing us with the data on the choice between the annuity and the lump sum payment. We thank CentERdata at Tilburg University for supplying the data of the DNB Household Survey. The paper has benefited from useful comments at the 14th International Business Research conference (Dubai, UAE, April 2011 - Best Paper Award), 9th International Workshop on Pension, Insurance and Saving (Paris, May 2011), International Journal of Arts Sciences conference (Bad Hofgastein, Austria, May 2011), 17th conference of the Society of Computational Economics - Computing in Economics and Finance (San Francisco, June 2011), 4th Society for the Study of Economic Inequality Conference (Catania, July 2011), Singapore Economic Review Conference (Singapore, August 2011), 67th International Institute of Public Finance Congress (Ann Arbor, Michigan, August 2011) and at DNB seminars. The views expressed in this paper are those of the author and do not necessarily reflect those of the institutions she belongs to. Any remaining errors are our own responsibility.

t Contact details: F.Teppa@,dnb.nl
} 


\section{Introduction}

Life expectancy has improved substantially since the past decades and it has accelerated in the recent years in all developed countries. In the Netherlands this phenomenon is particularly strong for males. According to the most recent World Health Statistics, life expectancy at birth has gone from 74 years in 1990 to 78 years in 2008 for males, and from 80 years in 1990 to 82 years in 2008 for females. In the same period, adult mortality rate, defined as the probability of dying between 15 and 60 years, has decreased from 11.6 percent to 7.8 percent for males, and from 6.7 percent to 5.7 percent for females. The declining female advantage in life expectancy is observed in the US as well (Vallin, 1991) and largely driven by behavioral factors (namely smoking) rather than biological factors (Pampel, 2002). In an increasingly ageing society the need to provide with adequate insurance for late-life consumption has become a high priority item in the agenda of the policy makers.

As the only contract that acts as insurance against longevity risk, the annuity should always be chosen by risky individuals, even in presence of bequest motives (Yaari 1965; Davidoff et al. 2005). Yet the empirical evidence from several countries shows that only a minor fraction of individuals voluntarily buys annuities (James and Song 2001; Johnson et al. 2004; Beatrice and Drinkwater 2004). The combination of these two facts is known as the "annuitization puzzle".

The annuitization puzzle is a well documented phenomenon in the literature. Several potential explanations have been discussed extensively in the literature. They include both supply side reasons, e.g. highly priced annuities due to adverse selection and administrative costs (Brown et al. 1999, 2001 for the US; Cannon and Tonks 2004, Finkelstein and Poterba 2004 for the UK), and demand side motives, e.g. intra-family risk sharing (Kotlikoff and Spivak 1981), liquidity constraints and large out-of-pocket health expenditures (Palumbo 1999; De Nardi et al. 2010), preference for bequests (Friedman and Warshawsky 1990; Vidal-Melia and Lejarraga-Garcia 2006). More recently alternative typically behavioural explanations have been found, e.g. framing effects or default effects (Bütler and Teppa 2007; Agnew (et al.) 2008; Brown et al. 2008).

This paper follows a different approach in that it focuses on longevity risk, a driver that should be key in this type of choice and that has been missing in the analysis so far. There are several ways to elicit information about individual life expectancy, both indirectly, looking at parental longevity, or directly, by asking subjective survival probabilities (SSP from now on). Both measures suffer from several drawbacks (e.g. focal points, rounding effects) but overall they seem to 
convey meaningful information on the individual longevity. There is evidence from the Health and Retirement Survey (HRS) that SSP contain useful information on survival expectations. They have been found to be correlated with known mortality risk factors, to predict actual mortality, although less well once self-assessed health is controlled for (Siegel et al. 2003), and are claimed to closely approximate actuarial survival probabilities on average (Hurd and McGarry 1995; Smith et al. 2001; Hurd and McGarry 2002). The English Longitudinal Study of Ageing (ELSA) data have been used to test the predictive power of SSP for actual mortality and a systematic underestimation of survival chances relative to those given in actuarial life tables has been noted (Banks et al. 2004; O'Donnell et al. 2008). More recently, SSP for the Netherlands have been used to analyze their impact on retirement intentions and actual behaviour (van Solinge and Henkens 2010).

In this paper we use subjective survival probabilities as measures of perceived longevity risk in a simple model for individual preferences over annuities and lump sum payments based on hypothetical questions posed in the DNB Household Survey in 2005. We find that people expecting to live longer do claim to prefer the annuity. This finding is very robust to controlling for bequest motives, that turns out to be the other main determinant for the choice of lump sum payments. The relevance of this paper is twofold. First, it delivers an important empirical result on the role of the SSP that is still not directly tested in the literature. Second and more important, combined with the empirical evidence that on average individuals tend to systematically underestimate their life expectancy, the findings have strong policy implications. The annuitization puzzle may be alleviated by helping individuals in better assessing their longevity risk, rather than forcing their final actions.

The paper is organized as follows. Section 2 describes the data used in the empirical analysis. Particular emphasis is devoted to the subjective survival probability, on how it has been elicited and on how it relates to the main individual background and socio-economic characteristics. Section 3 describes the empirical model with a focus on the dependent variable and the sample restrictions. Section 4 reports and discusses the empirical results. Section 5 concludes.

\section{The data}

The empirical analysis is based on data collected from the households participating in the so-called DNB Household Survey (DHS). The DHS, formerly known as the CentER Savings Survey, is an annual panel survey of more than 2,000 households in the Netherlands that started in 1993. The panel is run at Tilburg University by 
CentERdata. Panel members are aged 16 years and older. In case of attrition, CentERdata recruits new participants to maintain the panel size and to keep the panel as representative as possible on a number of relevant background characteristics such as age, gender, income, education, and region of residence. The DHS dataset further contains detailed information on employment status, pension arrangements, accommodation, wealth, as well as health status, and psychological concepts. The dataset thus provides the opportunity to combine both economic and psychological aspects of financial behavior.

\subsection{The subjective survival probability (SSP)}

This paper focuses on longevity risk and its impact on the choice between an annuity and a lump sum payment. In this study we use survey questions on subjective survival probabilities available for 2005. We then merge these data with the 2005 DHS wave in order to have all the relevant information present in the survey.

The life-expectancy questions given to the respondents have the following format which strictly follows the one used in the HRS as well as in the ELSA:

Please indicate your answer on a scale of 0 to 10, where 0 means "no chance at all" and 10 means "absolutely certain".

SSPXX : How likely is it that you will attain (at least) the age of XX?

The target age (denoted by XX) depends on the current age of the respondent. In particular, SSP75 is presented to people aged between 16 and 64; SSP80 is presented to people aged between 16 and 69; SSP85 is presented to people aged between 65 and 75; SSP90 is presented to people aged between 70 and 80; SSP95 is presented to people aged between 75 and 85; SSP100 is presented to people aged between 80 and 90. Since the answers are on a $0-10$ scale, we can interpret value 1 as " 1 to 10 percent likely to attain (at least) the age of XX", value 2 as "11 to 20 percent likely to attain (at least) the age of XX", and so forth. This format is very similar to that used by van Solinge and Henkens (2010), even if they ask this probability on a 1 to 5 scale, and they only ask for the target age of 75 . It is also important to note that by question design these probabilities are conditional on being alive at a certain age.

Table 1 presents the main summary statistics and Figure 1 shows the histograms for each subjective survival probability. A careful analysis of these statistics is needed in order to assess the informative content and to validate the overall quality of the various SSPs.

Table 1 and Figure 1 about here 
The number of observations decreases severely as the target age increases, as a consequence of the routing in the question design. However, we can infer that the several SSPs have a consistent and informative content. We note that both the mean and the median value of the SSPs monotonically decline with respect to the target age. The standard deviation is highest for SSP90 and SSP95, lowest for SSP100 and rather stable for the remaining SSPs. Several dispersion measures, like the variance and the standard error of the mean, provide some evidence that the respondents report lower chances to attain higher target ages, but they are also more uncertain about that, except for reaching age 100 .

The distributions are all non-symmetric but differ with respect to their skewness, which is negative for the three lowest target ages and positive for the three highest target ages. The most left-skewed distribution, with relatively few low values, and the most right-skewed distribution, with relatively few high values, are those for the extreme target ages, namely SPP75 and SPP100, respectively. This means that it is most likely to attain age 75 and least likely to attain age 100. In addition, the skewness monotonically increases with the target age; for SSP85 the distribution has roughly zero skewness and is unimodal ( mean $=$ median $=$ mode $=5$ ).

Finally, in order to assess whether the data are peaked or flat relative to a normal distribution we report the kurtosis. We observe that the histogram with the highest kurtosis is that for SSP75, with a distinct peak near the mean value.

\subsection{SSPs and socio-economic variables}

The DHS contains a great amount of information on several background as well as socio-economic characteristics, both at the individual and at the household level. In this section we make an overview of how the SSPs relate to some of these variables, in particular to those for which it is reasonable to expect a meaningful relationship. We know for example from mortality tables that females have a higher life expectancy than male, on average. Similarly, there is some empirical international evidence about a positive correlation between life expectancy and education level, as well as financial situation. We also expect SSP to be associated with health status, both subjectively reported and derived from more objective illnesses. With these ideas in mind, we select gender, education level, self-assessed health (SAH from now on), long-term illness, smoking behaviour, drinking habits, and household income. Table 2 reports the mean values of each SSP by background and socio-economic factors.

Table 2 about here 
The findings for gender are rather mixed. Women tend to report higher survival probabilities than man on average, but only in one case out of six this difference is statistically significant (at the 5-percent level). Moreover, in two cases (namely SSP85 and SSP90) this difference is negative, though not significant. This findings contrasts with international evidence of women living longer than men, on average. We thus devote a deeper thought on this in the next subsection.

The evidence for education level is more consistent, as the respondents with better education tend to have higher survival probabilities on average for all target ages up to 90. This health protective role of education is in line with Cutler, LlerasMuney and Vogl (2010). In addition, the difference for SSP75 is strongly significant (1-percent level) whereas that for SSP80 is less significant (10-percent level). For the two highest target ages, the difference turns out to be positive, and also significant at the 5-percent level for SSP95. This finding is rather counterintuitive, but could be (partly) explained by selective mortality.

A much more consistent picture is found for self-assessed health. For all target ages the individuals reporting good or very good SAH systematically report higher average survival probabilities than those with fair, bad or very bad SAH. The differences are always strongly significant. Similar evidence is found for long-term illness. The respondents who claim to suffer for LT illness significantly report lower survival probabilities than those who claim to have no LT illness, on average.

Both smoking and drinking behaviour seems to be only weakly related to SSPs. In both cases higher survival probabilities are reported by the respondents who declare to be non-smokers and to drink no alcohol, but the difference is strongly significant (at the 1-percent level) for the two lowest target ages only.

Finally, the SSP measures do not seem to be related at all with household income. We experimented with several cut-off points in household income, but the findings of no correlation are rather robust. This finding seems to be in line with Deaton's findings that as far as controllable vs. non-controllable diseases (e.g. cardiovascular vs. all cancer types) is concerned, among adults income is not important, but education is. In particular Deaton finds that education is health protective for controllable diseases only, whereas income is never health protective.

\subsection{Subjective vs. actuarial survival probabilities}

Another aspect that should be taken into account in assessing the quality of the SSPs is to relate them to actuarial survival probabilities. Do individuals perceive their longevity risk (and consequently form their subjective probabilities) correctly? 
To answer this question we compare the subjective survival probabilities from survey data to the actuarial survival probabilities from official mortality tables.

Actuarial survival probabilities are computed from mortality rates provided by Statistics Netherlands (CBS, Centraal Bureau voor de Statistiek). Since the DHS data refer to 2005, we consider the 2005 actuarial mortality rates, by age and gender. In order to make the two series of survival probabilities comparable, we construct the subjective survival probabilities implied by the SSPs by transforming the SSPs from the 1-10 scale into percentages.

Figure 2 reports the two series of statistics for the survival probabilities of reaching (at least) age 75. We only consider individuals aged 50+, for whom this kind of comparison is not affected by potential cohort effects. The upper panel refers to females; the lower panel refers to males.

The figure clearly shows that females underestimate their survival probabilities at all ages. For some ages this underestimation is quantitatively very strong (around 25 percentage points for age 52 and age 60). Similar evidence is found in the HRS data for United States by Perozek (2008).

Though evidence of substantial misperception of longevity risk for males as well is there, males seems to assess their survival probabilities better than females.

The fact that males have a better clue of their true survival probabilities explains the surprisingly mixed picture that emerges from Table 2 above. The demographic trend of women living longer than men, on average, is not mirrored in the reported subjective survival probabilities by gender mainly as a consequence of the stronger misperception of the actuarial survival probabilities by females than by males.

Overall, the empirical evidence documented so far seems to point to the conclusion that the SSPs, though neither perfect nor exempt from limitations, convey reasonably meaningful information on individual longevity, and relate relatively well with a number of background and socio-economic characteristics, on average. These findings are fully in line with van Solinge and Henkens (2010).

At the same time, the comparison between subjective and actuarial survival probabilities shows that individuals systematically underestimate their longevity, in some cases very strongly, especially for females. These findings are again fully in line with international figures (e.g. O'Donnell et al. 2008 for UK).

Figure 2 about here 


\section{The empirical model}

\subsection{The dependent variable}

The dependent variable in our models is derived from hypothetical questions on preferences over a full annuity or a partial lump sum payment upon retirement. The first question reads as follows:

Imagine you are 65 years old, and you are receiving $€ 1,000$ per month in state pension. Suppose you were given the choice to lower that benefit by half, to $€ 500$ per month. This one-half benefit reduction would continue for as long as you live. In return you would be given a one-time, lump sum payment of [€ 87,000 (for females) / € 72,000 (for males)].

Would you take the $€ 1,000$ monthly benefit for life, or the lower monthly benefit combined with the lump sum payment?

This initial question is asked to all respondents in the sample, irrespective of their working status and for all ages. At this stage, the respondents are given a fair deal. The lump sum payment is computed to be actuarially fair and thus the amount differs by gender: Females are confronted with a payment of 87,000 euros, males with 72,000 euros. The choice is then between a full annuity and a partial lump sum payment. For simplicity, from now on we omit the words "full" and "partial" when referring to the annuity and the lump sum payment, respectively. However, it is important to keep in mind, especially when interpreting the empirical results, that the other polar case of full lump sum payment is never offered to the individuals in this exercise.

Depending on the answer given to this question, the respondents are asked a follow-up question, where the lump sum payments is made more (less) attractive to those individuals who had preferred the annuity (the lump sum payment) in the first round. Figure 3 reports the structure of the question sequence. Table 3 reports the mean values of the choice between the annuity and the lump sum payments for the full sample, as well as by gender and by the presence of children.

\section{Figure 3 and Table 3 about here}

The annuity is preferred by slightly more than half of respondents ( 54 percent) in Question 1.1 Conditional on having chosen the annuity in Question 1, then the

\footnotetext{
${ }^{1}$ This is in line with Brown (2001) who finds that 48 percent of the HRS sample reports that they will annuitize their DC plan.
} 
annuity is still largely preferred to the lump sum payment in Question 2a (69 percent vs. 31 percent, respectively). Similarly, conditional on having chosen the lump sum in Question 1, then the annuity is preferred only by 40 percent of individuals in Question 2b. There is evidence of persistent preferences as only 17 percent of individuals switch from the annuity to the lump sum payment (172 out of 1,027), and only 18 percent of individuals switch from the lump sum payment to the annuity (185 out of 1,027 ).

The overall picture does not change when the choice is made by gender and by the presence of children. We notice however that males and respondents without children prefer the annuity the most (57 and 56 percent respectively) in Question 1. Both the difference with females and the difference with people with no children are significant at the 5-percent level in Question 1. No significant differences by gender or by having children is found for the follow-up questions. We also made the analysis (not reported in the table) by the presence of partner and household income: the differences are non significant.

It is important to notice that the framing of this question is not fully "neutral" as it involves an explicit opting-out option (a lump sum payment in place of half annuitized pension wealth). This set up was used in the 2004 wave of the HRS. In the 2008 wave of the HRS a somewhat different wording was used in order to elicit the information about willingness to annuitize:

Imagine you are 65 years old, and you are receiving \$1,000 per month in Social Security benefits. Imagine that you are currently getting \$1,000 per month in Social Security benefits. Suppose you had a choice: either you could keep that $\$ 1,000$ monthly benefit for life, or you could exchange it for a monthly benefit half that size, $\$ 500$ per month for life, plus youd get a one-time, lump sum payment.

What is the smallest lump-sum that you would be willing to accept in exchange for reducing your lifetime benefit by $\$ 500$ per month? \$ .... Amount

We model the choice between the annuity and the lump sum payment by a standard binary choice model, where the dependent variable takes value 1 if the annuity is chosen in Question 1, 0 if the lump sum payment is preferred in that same question. We then perform simple probit regressions.

\subsection{Sample restrictions}

Contrary to Bütler and Teppa (2007), who provide with empirical evidence on actual choices, this paper is based on purely hypothetical choices between the annuity and the lump sum. In order to make this choice as close to reality as possible, we restrict 
our analysis primarily on the subsample of the respondents aged less than 65 years old. This subgroup consists of 80 percent of the initial sample, and includes the individuals for whom this choice, thought hypothetical, might be more meaningful. In real circumstances, in fact, this choice is typically given upon retirement or some years prior to the retirement date. We therefore exclude the oldest fraction of the sample population altogether, e.g. those aged $70+2^{2}$ and we keep the individuals aged 65-69 to perform some robustness analysis.

Another dimension we restrict our attention upon is the question sequence. We conduct most of our empirical analysis on the initial, reported above, question only, and use the follow-up questions for an extension and robustness checks. The idea behind this strategy lies on the fact that Question 1 only in Figure 3 presents an actuarially fair deal to the respondents. In order to assess the role of the longevity risk on this choice it is very important to start with an environment where one option is not preferrable to the other due to opportunity biases. On the other hand, it is straightforward to think that in case an individual knows for sure that she will not survive until a certain age the lump sum payment is always to prefer even if it is not fair compared to the annuity.

\section{Empirical findings}

\subsection{Does the annuity demand respond to longevity risk?}

Table 4a reports the first set of empirical findings. The "baseline" specification includes longevity risk (via the subjective survival probability to age 75, SSP75), age (in quadratic form) and gender (as a female indicator), and other forms of old age provision (through a dummy variable for the presence of other pension arrangements besides the standard pension built up through one's employer). In particular, the dummy takes value 1 if any of the following arrangements have been purchased: annuities, life policies, extra pension rights via the employer, extra periodical payments via the employer, other pension funds.

Two additional specifications aim at controlling for bequest motives. We refer to them as the "augmented" and the "restricted" specifications, respectively. The augmented specification contains the variable "Bequest" derived from the following question:

What is the chance that you will leave an inheritance (including possessions and

\footnotetext{
${ }^{2}$ They represent 13 percent of the initial sample.
} 
valuable items) of more than $€ 10,000$ ?

The restricted specification replicates the augmented version but only to the subgroup of individuals who answered option (1) or option (2) to the following question:

Please indicate which of the following four statements about parents leaving a bequest to their children would be closest to your own opinion about this.

(1) If our children would take good care of us when we get old, we would like to leave them a considerable bequest;

(2) We would like to leave our children a considerable bequest, irrespective of the way they will take care of us when we are old;

(3) We have no preconceived plans about leaving a bequest to our children;

(4) We do not intend to leave a bequest to our children;

(5) None of the above-mentioned statements.

Table 4b slightly differs from Table 4a. In all three specifications we replace the variable "Other pension arrangements" by the purchase of life policies, which is one of the components included in the replaced variable. The idea behind this alternative specification is to assess the role of life policies alone as probably the most natural financial instrument that allows to cover the longevity risk.

Table $4 a$ and Table $4 b$ about here

The baseline scenario shows that in absence of bequest motives the individual choice between the annuity and the lump sum payment responds strongly significantly to the longevity risk and with the expected positive coefficient sign. The respondents reporting higher probabilities to survive (at least) until 75 years are more likely to opt for the annuity, at the 1-percent significance level. The marginal effect is such that for any additional 10 percent-point increase in the SSP75 the probability to annuitize increases by 2.6 percent on average. As an example, if the chance to be alive at age 75 increases from 30 to 40 percent, the probability to choose the annuity increases by 2.6 percent. An individual whose survival expectations at age 75 go from 0 percent to 100 percent increases her probability to annuitize by 26 percent.

Age enters significantly (at the 5-percent level) with both its terms. The age function for choosing the annuity is U-shaped and reaches a minimum at age 38 . This finding is in line with the analysis conducted on real choices over the lumpsum versus annuity payout made by retirement-age participants in two Fortune 
500 defined benefit plans (one a traditional final-average-pay plan, the other a cash balance plan) in the US, where older participants were much more likely to annuitize than their younger counterparts. Approximately half of the participants aged 70 and older chose an annuity compared with less than 20 percent for participants between ages 55 and 60 (Mottola and Utkus, 2007). We estimate that a one-year increase in age leads to a marginal increase in the probability to annuitize by 3 percent, on average. Mottola and Utkus (2007) found that a five-year increase in age is associated with an eight (seven) percentage point increase in the likelihood to annuitize in the traditional plan (in the cash balance plan).

Females annuitize significantly less than males: being a female decreases the probability to annuitize by 8.2 percent, at the margin. The higher cash out rates for women are fully consistent with the findings of Bütler and Teppa (2007) and can be mostly explained by the availability of alternative sources of income and insurance (husband, family). Having other pension arrangements reduces the probability to annuitize. This finding is in line with our priors because alternative forms of savings devoted specifically to cover the longevity risk may act as substitutes for annuities. However, the significance level is rather low (10 percent) and the marginal effect is 6.2 percent.

Controlling for the probability of leaving a bequest (augmented specification) does not affect the impact of the subjective survival probability: the individuals expecting higher probability of being alive (at least) at age 75 are more likely to annuitize. The marginal effect of SSP75 remains robust (2.5 percent for every 10 percent change in SSP75), the significance level is somewhat less strong than in the baseline specification but still satisfactory (5-percent level). The age effect vanishes away, but gender and the presence of alternative pension arrangements stay robust, with slightly larger marginal effects (9.4 percent and 7.8 percent, respectively). The extra variable for bequest motives does not play any significant role.

When refining the concept of leaving a bequest and restricting the sample to the individuals who answered the last question above mentioned, despite the severe drop in the number of observations, the bequest motive gets significant (at the 5percent level) and with the expected negative sign. At the same time, the longevity risk remains significant (although only at the 1-percent level) and with the positive sign. All the other regressors loose their predictive power. It seems that the choice between an annuity and a (partial) lump sum payment is mainly driven by the longevity risk (with a more than double marginal effect) and by the bequest motive. These two drivers are opposite to each other, and the empirical findings show that the bequest motive does not dominate the longevity risk. These findings are very 
robust to replacing "Other pension arrangements" with "Life policies" (see Table 4b). The SSP75 remains very significant even when controlling for the intention to leave a bequest and its marginal effect is always larger in all three specifications. The desire to bequeath is the other strongly significant determinant on the annuitization choice.

We ran alternative specifications by including additional background characteristics (e.g. level of education, marital status, number of children), financial assets (e.g. household income and household wealth, both net and gross), and health variables (e.g. self-assessed health, number of visits to the medical doctor). All these controls turned out to be totally insignificant, but rather correlated with the subjective survival probabilities. We then decided not to report all these regressions, but rather concentrate on the above mentioned specifications.

\subsection{Do different time horizons in measuring longevity risk matter?}

The empirical evidence described in the previous subsection is based on the subjective survival probabilities to age 75 (SSP75). However, our data asks the respondents aged less than 70 years old a similar question for a slightly longer time horizon, namely about the subjective survival probabilities to age 80 (SSP80). In other words, for the subsample of individuals aged less than 65 we focus upon both questions on longevity risk are available.

Table 5a and Table 5b present the empirical findings when controlling for this longer time horizon (SSP80 instead of SSP75). The model specifications are also the same as the ones used in Table $4 \mathrm{a}$ and Table $4 \mathrm{~b}$ respectively. The aim of this exercise is to investigate whether different time horizons have a different impact on the annuitization choice. For this reason, the models in Table 5a and Table 5b have been estimated for the same subsample of respondents as for Tables $4 \mathrm{a}$ and $4 \mathrm{~b}$, namely the respondents aged less than 65 .

\section{Table $5 a$ and Table $5 b$ about here}

The picture that derives from this set of regressions is fairly similar to the one presented in the previous subsection. The SSP80 does a proper job in explaining the choice between the annuity and the lump sum payment, as well as the background characteristics and the financial variables. However we note that in the restricted specification the longevity risk looses now its significance whereas the bequest variable keeps being significant. Of course the yery small number of observations induces 
the reader to be very careful in drawing strong conclusions. However, there is some evidence that making the survival horizon longer (e.g. asking the survival probability in a 5-year longer period) hampers its predictive power. This finding is deemed to be investigated more deeply, as it may create some concerns for policy makers who are ultimately faced with the individual risk of reaching very high ages.

As robustness check, we perform the same analysis also for the subsample of individuals aged less than 70 for which we have the full answers to SSP80. The overall picture does not change. However, we do not report a separate table for space reasons.

\subsection{Does the distance to the retirement age matter?}

As mentioned earlier, in real circumstances the choice between an annuity and a lump sum payment is typically to be taken upon retirement. In principle this choice is restricted to a particular subgroup of the eligible population, that could act as a sort of target group. We have already documented in the previous sections that the respondents' age play a role, sometimes very significant, on this choice. The survey nature of our data allows to investigate further along this dimension. In this section we address the question whether the individuals choose differently depending on how close they are to the retirement age, which is 65 years old.

We select two subsamples of respondents for which we have a reasonable number of observations: those aged 49-64, and those aged 55-64. For each of these subsamples, we perform the baseline specification under three variants: without SSP, with SSP75, and with SSP80. The results are reported in Table 6.

\section{Table 6 about here}

We observe that the two selected subgroups do not seem to be very heterogeneous. In both cases the choice consistently and significantly depends on the SSPs. Females are more likely to cash out than males in both subgroups, but significantly (though only at the 10-percent level) for the 49-64 respondents. Though the age variables are not significant, we note that the age functions for the two subgroups are very different. Figure 4 show that the age functions are inverse U-shaped for those aged 49-64, and U-shaped for those aged 55-64.

$$
\text { Figure } 4 \text { about here }
$$




\subsection{Are annuity people different from lump sum people?}

The analysis conducted so far has been based on Question 1 only in Figure 3. However we also observe the choice the respondents make in the follow-up questions. In order to investigate the robustness of the SSPs as important, if not the main, driving determinants of the choice between the annuity and the lump sum payment we now run probit analysis with two slightly different dependent variables. In one case we code as 1 those individuals who choose the annuity option in both rounds, namely both in Question 1 and in Question 2a. For simplicity we label these respondents as "annuity people" . In the other case we code as 1 those individuals who choose the lump sum option in both rounds, namely both in Question 1 and in Question

2b. For symmetry we label these respondents as "lump sum people" . For both specifications we run the augmented and the restricted specification, with SSP75 and SSP80. Table $7 \mathrm{a}$ and Table $7 \mathrm{~b}$ report the results for this set of regressions.

Table Ya and Table 7b about here

As before, both the annuity people and the lump sum people consistently choose in line with their subjective survival probabilities. Both SSP75 and SSP80 affect positively the annuity choice and negatively the lump sum payment choice. The usual significance levels are always satisfied, with the only exception of the restricted specification for the annuity choice. In addition, bequest motives appear to be the other most relevant determinant of both the annuity and the lump sum choice. The opposite coefficient signs for the two subgroups are in line with ex-ante predictions. The respondents who intend to leave a bequest do annuitize less and do cash out more. In both cases the value of the marginal effect is the same and rather small (0.003), and the significance is at the 1-percent level.

\section{Conclusions}

This paper provides new evidence on individual preferences over annuities and lump sum payments based on hypothetical questions posed in the DNB Household Survey in 2005. Contrary to the majority of papers in the annuitization puzzle literature, this study allows to control explicitly for the subjective survival probability (SSP), a key driver of the decision about whether to annuitize or not as a measure of perceived longevity risk.

The main results can be summarized as follows. Firstly, we find that the SSPs convey reasonably meaningful information on individual longevity, and relate relatively well with a number of background and socio-economic characteristics, on 
average. Secondly, individuals make their choices consistently in line with their survival expectations. In particular, the people expecting to live longer do claim to prefer the annuity. This finding is very robust to a number of alternative specifications, including regressions where bequests motives are explicitly taken into account. Overall, the choice seems to be significantly driven by these two opposite forces. All the other controls are totally irrelevant for the choice: Education level, but also household income (net and gross), household wealth (net and gross), the presence of (dependent) children, marital status do not have any significant role on the choice between the annuity and the lump sum payment.

We plan to extend this paper in a number of directions. A deeper understanding of the role of the SSPs is deemed to be necessary. In order to do so, we are going to investigate the effect of longer horizons by asking the individuals for which the choice between the annuity and the lump sum is potentially relevant the subjective probability of reaching very high target ages, like 90 , or 95, or even longer. The idea is to test whether the findings of a very strong role of these SSPs remain robust when far off ages are involved. This is ultimately the longevity risk policy makers are concerned about. While writing this version of the paper, the new questions are being fielded.

Another direction we intend to undertake is to frame the choice between the annuity and the lump sum differently and test for the presence of framing/wording effects. This experiment is left for future research.

The relevance of this paper is twofold. First, it delivers an important empirical result on the role of the SSP that is still not directly tested in the literature about the annuitization puzzle. In addition, given that on average individuals tend to systematically underestimate their life expectancy, the finding that people choose the annuity consistently with respect to their survival probabilities have strong policy implications. The annuitization puzzle may be alleviated by helping individuals in better assessing their perceived longevity risk, rather than forcing their actions. 


\section{References}

[1] Agnew, J., Anderson, L., Gerlach, J. and Szykman, L. (2008), "Who chooses annuities? An experimental investigation of gender, framing and defaults", American Economic Review, 98(2), 418-422.

[2] Banks, J., Emmerson, C. et al. (2004), "Not so brief lives: longevity expectations and wellbeing in retirement", Seven Ages of Man and Woman: A Look at Life in Britain in the Second Elizabethan Era I. Stewart and R. Vaitlingam. Swindon, ESRC.

[3] Beatrice, D., Drinkwater, M. (2004), "The 2003 individual annuity market: Sales and assets", Tech. rep., LIMRA International, Inc, Windsor, CT.

[4] Brown, J., Mitchell, O., Poterba, J. and Warshawsky, M. (1999), "New evidence on the money's worth of individual annuities", American Economic Review 89, 1299-1318.

[5] Brown, J., Mitchell, O., Poterba, J. and Warshawsky, M. (2001), The role of annuity markets in financing retirement, MIT press, Cambridge, USA.

[6] Brown, J., Kling, J., Mullainathan, S. and Wrobel, M. (2008), "Why dont people insure late-life consumption? A framing explanation of the underannuitization puzzle", American Economic Review 98(2), 304309.

[7] Bütler, M. and Teppa, F. (2007), "The choice between an annuity and a lump sum: Results from Swiss pension funds", Journal of Public Economics 91, 19441966.

[8] Cannon, E. and Tonks, I. (2004), "UK annuity rates, money's worth and pension replacement ratios, 1957-2002", The Geneva papers on risk and insurance 29(3), 394-416.

[9] Cutler, D., Lleras-Muney, A. and Vogl, T. (2010), "Socioeconomic status and health: Dimensions and mechanisms", Oxford Handbook of Health Economics forthcoming.

[10] Davidoff, T., Brown, J. and Diamond, P. (2005), "Annuities and individual welfare", American Economic Review 95(5), 1573-1590.

[11] De Nardi, M., French, E. and Jones, J. (2010), "Why do the elderly save? The role of medical expenses", Journal of Political Economy 118(1), 39-75. 
[12] James, E., Song, X. (2001), “Annuities markets around the world: Money's worth and risk intermediation", CeRP WP16.

[13] Johnson, R., Burman, L., Kobes, D. (2004), "Annuitized wealth at older ages: Evidence from the Health and Retirement Study", Final Report to the Employee Benefits Security Administration, U.S. Department of Labor 9142, The Urban Institute, Washington, DC.

[14] Finkelstein, A. and Poterba, J. (2004), "Adverse selection in insurance markets: Policyholder evidence from the U.K. annuity market", Journal of Political Economy 112(1), 183-208.

[15] Friedman, B. and Warshawsky, M. (1990), "The cost of annuities: Implications for saving behavior and bequests", The Quarterly Journal of Economics 105(1), 135-154.

[16] Hurd, M. and McGarry, K. (1995), "Evaluating subjective probabilities of survival in the Health and Retirement Study", Journal of Human Resources S268S292.

[17] Hurd, M. and McGarry, K. (2002), "The predictive validity of subjective probabilities of survival", Economic Journal 112(442), 966-985.

[18] Kotlikoff, L. and Spivak, A. (1981), "The family as an incomplete annuities market", Journal of Political Economy 89(2), 372-391.

[19] Mottola, G. and Utkus, S. (2007), "Lump sum or annuity? An analysis of choice in DB pension payouts", Vanguard Center for Retirement Research 30. 89(2), 372-391.

[20] O’Donnell, O., Teppa, F. and van Doorslaer, E. (2008), "Can subjective survival expectations explain retirement behaviour?", DNB WP188.

[21] Palumbo, M. (1999), "Uncertain medical expenses and precautionary saving near the end of the life cycle", Review of Economic Studies 66(2), 395-421.

[22] Pampell, F. (2002), "Cigarette use and the narrowing sex differential in mortality", Population and Development Review, 28(1), 77104.

[23] Perozek, M. (2008), "Using subjective expectations to forecast longevity: Do survey respondents know something we don't know?", Demography, 45(1), 95113. 
[24] Siegel, M., Bradley, E. et al. (2003) "Self-rated life expectancy as a predictor of mortality: Evidence from the HRS and AHEAD surveys", Gerontology 49, 265-71.

[25] Smith, V., Taylor, D. et al. (2001) "Longevity expectations and death: Can people predict their own demise?", American Economic Review 91(4), 11261134.

[26] Solinge, H. van and Henkens, K. (2010), "Living longer, working longer? The impact of subjective life expectancy on retirement intentions and behaviour", European Journal of Public Health 20(1), 47-51.

[27] Vallin, J. (1991), "Mortality in Europe from 1720 to 1914: long-term trends in patterns by age and sex", in R. Schofield, D. Reher, and A. Bideau, eds., The decline of mortality in Europe, Oxford University Press.

[28] Vidal-Melia, C. and Lejarraga-Garcia, A. (2006), "Demand for life annuities from married couples with a bequest motive", Journal of Pension Economics and Finance 5(2), 197-229.

[29] Yaari, M. (1965), "Uncertain lifetime, life insurance, and the theory of consumer", Review of Economic Studies 32, 137-150. 
Table 1: Summary statistics for SSPs

\begin{tabular}{||l|c|c|c|c|c|c||}
\hline \hline Statistics & SSP75 & SSP80 & SSP85 & SSP90 & SSP95 & SSP100 \\
\hline Mean & 6.90 & 5.68 & 5.24 & 3.63 & 2.64 & 0.57 \\
Median & 7 & 6 & 5 & 4 & 2 & 0 \\
Std.Dev. & 1.93 & 2.26 & 2.13 & 2.40 & 2.35 & 0.76 \\
Variance & 3.75 & 5.11 & 4.56 & 5.79 & 5.54 & 0.59 \\
Std.Err.(mean) & 0.06 & 0.07 & 0.16 & 0.20 & 0.28 & 0.17 \\
Skewness & -0.91 & -0.49 & -0.08 & 0.23 & 0.84 & 0.86 \\
Kurtosis & 4.14 & 2.87 & 2.71 & 2.33 & 3.26 & 2.29 \\
\hline N.Obs. & 931 & 1018 & 174 & 138 & 68 & 19 \\
\hline \hline
\end{tabular}


Table 2: SSPs and socio-economic factors (mean values)

\begin{tabular}{|c|c|c|c|c|c|c|}
\hline Variable & SSP75 & SSP80 & SSP85 & SSP90 & SSP95 & SSP100 \\
\hline \multicolumn{7}{|l|}{ GENDER } \\
\hline Female & 6.92 & 5.82 & 5.11 & 3.22 & 3.62 & 0.67 \\
\hline Male & 6.87 & 5.56 & 5.31 & 3.77 & 2.52 & 0.56 \\
\hline Difference & 0.05 & $0.26^{* *}$ & -0.20 & -0.55 & 1.10 & 0.11 \\
\hline \multicolumn{7}{|l|}{ EDUCATION LEVEL } \\
\hline Low level & 6.60 & 5.50 & 5.01 & 3.34 & 3.34 & 0.83 \\
\hline Mid/high level & 6.99 & 5.74 & 5.37 & 3.78 & 2.28 & 0.46 \\
\hline Difference & $-0.38 * * *$ & $-0.23 *$ & -0.36 & -0.43 & $1.05 * *$ & 0.37 \\
\hline \multicolumn{7}{|l|}{$\mathrm{SAH}$} \\
\hline Good/Very good & 7.19 & 5.98 & 5.74 & 4.25 & 3.11 & 0.57 \\
\hline Fair/Bad/Very bad & 5.78 & 4.58 & 3.91 & 1.86 & 1.79 & 0.58 \\
\hline Difference & $1.41 * * *$ & $1.40^{* * *}$ & $1.83^{* * *}$ & $2.39 * * *$ & $1.32 * *$ & -0.01 \\
\hline \multicolumn{7}{|l|}{ LT ILLNESS } \\
\hline Yes & 6.36 & 5.17 & 4.90 & 3.08 & 2.37 & 0.60 \\
\hline No & 7.08 & 5.86 & 5.47 & 4.01 & 2.84 & 0.56 \\
\hline Difference & $-0.72 * * *$ & $-0.69 * * *$ & $-0.57 * *$ & $-0.92 * *$ & -0.46 & 0.04 \\
\hline \multicolumn{7}{|l|}{ SMOKE } \\
\hline Yes & 6.48 & 5.24 & 5.08 & 3.72 & 4.00 & 0.00 \\
\hline No & 7.05 & 5.82 & 5.26 & 3.61 & 2.53 & 0.64 \\
\hline Difference & $-0.56 * * *$ & $-0.58 * * *$ & -0.17 & 0.10 & 1.46 & -0.64 \\
\hline \multicolumn{7}{|l|}{ DRINK } \\
\hline Yes & 6.24 & 4.93 & 5.11 & 2.16 & 1.75 & 0.00 \\
\hline No & 6.94 & 5.73 & 5.24 & 3.69 & 2.70 & 0.64 \\
\hline Difference & $-0.69 * * *$ & $-0.79 * * *$ & -0.13 & $-1.53 *$ & -0.95 & -0.64 \\
\hline \multicolumn{7}{|l|}{ HOUSEHOLD INCOME } \\
\hline Larger than 40,000 euros & 6.86 & 5.59 & 5.29 & 3.60 & 2.63 & 0.64 \\
\hline Lower than 40,000 euros & 6.82 & 5.72 & 5.25 & 3.74 & 2.85 & 0.40 \\
\hline Difference & 0.32 & -0.13 & 0.04 & -0.14 & -0.22 & 0.24 \\
\hline $\begin{array}{l}* * * \text { denotes significant at } \\
* * \text { denotes significant at } 5 \\
* \text { denotes significant at } 10\end{array}$ & $\begin{array}{l}\text { 1-percent le } \\
\text {-percent lev } \\
\text {-percent lev }\end{array}$ & & & & & \\
\hline
\end{tabular}


Table 3: Mean values of the choice between annuity and lump sum payments

\begin{tabular}{|c|c|c|c|c|c|c|}
\hline \multirow[t]{2}{*}{ Choice } & \multicolumn{2}{|c|}{ Question 1} & \multicolumn{2}{|c|}{ Question 2a } & \multicolumn{2}{|c|}{ Question 2b } \\
\hline & Percent & N.Obs. & Percent & N.Obs. & Percent & N.Obs. \\
\hline \multicolumn{7}{|c|}{ FULL SAMPLE } \\
\hline Annuity & 54.24 & 557 & 68.56 & 375 & 40.13 & 185 \\
\hline Lump sum & 45.76 & 470 & 31.44 & 172 & 59.87 & 276 \\
\hline Total & 100 & 1,027 & 100 & 547 & 100 & 461 \\
\hline \multicolumn{7}{|c|}{ GENDER } \\
\hline FEMALE & & & & & & \\
\hline Annuity & 50.24 & 213 & 68.12 & 141 & 37.02 & 77 \\
\hline Lump sum & 49.76 & 211 & 31.88 & 66 & 62.98 & 131 \\
\hline Total & 100 & 424 & 100 & 207 & 100 & 208 \\
\hline MaLe & & & & & & \\
\hline Annuity & 57.05 & 344 & 68.82 & 234 & 42.69 & 108 \\
\hline Lump sum & 42.95 & 259 & 31.18 & 106 & 57.31 & 145 \\
\hline Total & 100 & 603 & 100 & 547 & 100 & 253 \\
\hline Difference & \multicolumn{2}{|c|}{$-6.81 * *$} & \multicolumn{2}{|c|}{-0.70} & \multicolumn{2}{|c|}{-5.67} \\
\hline \multicolumn{7}{|c|}{ CHILDREN } \\
\hline \multicolumn{7}{|l|}{ WITH CHILDREN } \\
\hline Annuity & 50 & 163 & 66.46 & 105 & 40.99 & 66 \\
\hline Lump sum & 50 & 163 & 33.54 & 53 & 59.01 & 95 \\
\hline Total & 100 & 326 & 100 & 158 & 100 & 161 \\
\hline No CHILDREN & & & & & & \\
\hline Annuity & 56.21 & 394 & 69.41 & 270 & 39.67 & 119 \\
\hline Lump sum & 43.79 & 307 & 30.59 & 119 & 60.33 & 181 \\
\hline Total & 100 & 701 & 100 & 389 & 100 & 300 \\
\hline Difference & \multicolumn{2}{|c|}{$-6.21^{* *}$} & \multicolumn{2}{|c|}{-2.95} & \multicolumn{2}{|c|}{1.31} \\
\hline $\begin{array}{l}* * * \text { denotes signif } \\
* * \text { denotes signific } \\
* \text { denotes significa }\end{array}$ & $\begin{array}{l}\text { cant at } 1-\mathrm{p} \\
\text { ant at } 5 \text {-pe } \\
\text { at at } 10-\text { pe }\end{array}$ & $\begin{array}{l}\text { ercent leve } \\
\text { cent level } \\
\text { cent level }\end{array}$ & & & & \\
\hline
\end{tabular}


Table 4a: Annuity choice and SSP75 - probit estimates

\begin{tabular}{|c|c|c|c|}
\hline Variable & $\begin{array}{l}\text { Baseline } \\
\text { Coefficient } \\
\text { [Marg.eff.] } \\
\text { (Std. Err.) }\end{array}$ & $\begin{array}{l}\text { Augmented } \\
\text { Coefficient } \\
\text { [Marg.eff.] } \\
\text { (Std. Err.) }\end{array}$ & $\begin{array}{l}\text { Restricted } \\
\text { Coefficient } \\
\text { [Marg.eff.] } \\
\text { (Std. Err.) }\end{array}$ \\
\hline SSP75 & $\begin{array}{c}0.064 * * * \\
{[0.026]} \\
(0.024)\end{array}$ & $\begin{array}{c}0.062 * * \\
{[0.025]} \\
(0.026)\end{array}$ & $\begin{array}{l}0.141 * \\
{[0.056]} \\
(0.081)\end{array}$ \\
\hline Age & $\begin{array}{c}-0.075 * * \\
{[-0.030]} \\
(0.037)\end{array}$ & $\begin{array}{c}-0.059 \\
{[-0.023]} \\
(0.039)\end{array}$ & $\begin{array}{c}-0.034 \\
{[-0.014]} \\
(0.146)\end{array}$ \\
\hline Age squared & $\begin{array}{c}0.001 * * \\
{[0.001]} \\
(0.000)\end{array}$ & $\begin{array}{l}0.001 * \\
{[0.001]} \\
(0.000)\end{array}$ & $\begin{array}{c}0.001 \\
{[0.001]} \\
(0.001)\end{array}$ \\
\hline Female & $\begin{array}{c}-0.206 * * \\
{[-0.082]} \\
(0.094)\end{array}$ & $\begin{array}{c}-0.236 \text { ** } \\
{[-0.094]} \\
(0.102)\end{array}$ & $\begin{array}{c}-0.252 \\
{[-0.099]} \\
(0.347)\end{array}$ \\
\hline Other pension arrangements & $\begin{array}{c}-0.155 * \\
{[-0.062]} \\
(0.094)\end{array}$ & $\begin{array}{c}-0.196 \text { ** } \\
{[-0.078]} \\
(0.101)\end{array}$ & $\begin{array}{c}-0.051 \\
{[-0.020]} \\
(0.319)\end{array}$ \\
\hline Bequest & & $\begin{array}{c}-0.002 \\
{[-0.001]} \\
(0.001)\end{array}$ & $\begin{array}{c}-0.014 \text { ** } \\
{[-0.005]} \\
(0.001)\end{array}$ \\
\hline Constant & $\begin{array}{c}1.002 \\
(0.821)\end{array}$ & $\begin{array}{c}0.765 \\
(0.896) \\
\end{array}$ & $\begin{array}{c}0.450 \\
(3.351)\end{array}$ \\
\hline $\begin{array}{l}\text { Log-likelihood } \\
\text { Pseudo } \mathrm{R}^{2} \\
\text { N.Obs. } \\
\text { Minimum annuity at age }\end{array}$ & $\begin{array}{c}-538.159 \\
0.027 \\
799 \\
38\end{array}$ & $\begin{array}{c}-471.579 \\
0.033 \\
705 \\
35\end{array}$ & $\begin{array}{c}-47.028 \\
0.103 \\
76 \\
26\end{array}$ \\
\hline \multicolumn{4}{|c|}{$\begin{array}{l}\text { The dependent variable is the annuity choice in the first round } \\
\text { Specification (I) : subsample } 22-64 \text { without bequest motive } \\
\text { Specification (II) : subsample } 22-64 \text { with bequest motive } \\
\text { Specification (III) : subsample } 22-64 \text { restricted to those intending to bequeath } \\
* * * \text { denotes significant at } 1 \text {-percent level } \\
\text { ** denotes significant at } 5 \text {-percent level } \\
* \text { denotes significant at } 10 \text {-percent level }\end{array}$} \\
\hline
\end{tabular}


Table 4b: Annuity choice and SSP75 - probit estimates

\begin{tabular}{|c|c|c|c|}
\hline Variable & $\begin{array}{l}\text { Baseline } \\
\text { Coefficient } \\
\text { [Marg.eff.] } \\
\text { (Std. Err.) }\end{array}$ & $\begin{array}{l}\text { Augmented } \\
\text { Coefficient } \\
\text { [Marg.eff.] } \\
\text { (Std. Err.) }\end{array}$ & $\begin{array}{l}\text { Restricted } \\
\text { Coefficient } \\
\text { [Marg.eff.] } \\
\text { (Std. Err.) }\end{array}$ \\
\hline SSP75 & $\begin{array}{c}0.074 \text { *** } \\
{[0.030]} \\
(0.029)\end{array}$ & $\begin{array}{c}0.072 * * \\
{[0.029]} \\
(0.031)\end{array}$ & $\begin{array}{c}0.239 * * \\
{[0.094]} \\
(0.081)\end{array}$ \\
\hline Age & $\begin{array}{c}-0.087 * \\
{[-0.035]} \\
(0.047)\end{array}$ & $\begin{array}{c}-0.078 \\
{[-0.031]} \\
(0.051)\end{array}$ & $\begin{array}{c}0.005 \\
{[0.002]} \\
(0.194)\end{array}$ \\
\hline Age squared & $\begin{array}{c}0.001 * * \\
{[0.001]} \\
(0.000)\end{array}$ & $\begin{array}{l}0.001 * \\
{[0.001]} \\
(0.000)\end{array}$ & $\begin{array}{c}0.001 \\
{[0.001]} \\
(0.002)\end{array}$ \\
\hline Female & $\begin{array}{c}-0.293 \text { *** } \\
{[-0.116]} \\
(0.114)\end{array}$ & $\begin{array}{c}-0.340 * * * \\
{[-0.135]} \\
(0.122)\end{array}$ & $\begin{array}{c}-0.669 \\
{[-0.261]} \\
(0.450)\end{array}$ \\
\hline Life policies & $\begin{array}{c}-0.290 * \\
{[-0.115]} \\
(0.302)\end{array}$ & $\begin{array}{c}-0.333 * \\
{[-0.132]} \\
(0.175)\end{array}$ & $\begin{array}{c}-0.971 \\
{[-0.367]} \\
(0.602)\end{array}$ \\
\hline Bequest & & $\begin{array}{c}-0.002 \\
{[-0.001]} \\
(0.001)\end{array}$ & $\begin{array}{c}-0.016 * * \\
{[-0.006]} \\
(0.002)\end{array}$ \\
\hline Constant & $\begin{array}{c}1.234 \\
(1.054)\end{array}$ & $\begin{array}{c}1.145 \\
(1.158)\end{array}$ & $\begin{array}{c}0.718 \\
(4.405)\end{array}$ \\
\hline $\begin{array}{l}\text { Log-likelihood } \\
\text { Pseudo } \mathrm{R}^{2} \\
\text { N.Obs. } \\
\text { Minimum annuity at age }\end{array}$ & $\begin{array}{c}-376.981 \\
0.033 \\
563 \\
39\end{array}$ & $\begin{array}{c}-333.780 \\
0.041 \\
503 \\
38\end{array}$ & $\begin{array}{c}-29.473 \\
0.222 \\
55 \\
-\end{array}$ \\
\hline \multicolumn{4}{|c|}{$\begin{array}{l}\text { The dependent variable is the annuity choice in the first round } \\
\text { Specification (I) : subsample } 22-64 \text { without bequest motive } \\
\text { Specification (II) : subsample } 22-64 \text { with bequest motive } \\
\text { Specification (III) : subsample } 22-64 \text { restricted to those intending to bequeath } \\
* * * \text { denotes significant at } 1 \text {-percent level } \\
\text { ** denotes significant at } 5 \text {-percent level } \\
* \text { denotes significant at } 10 \text {-percent level }\end{array}$} \\
\hline
\end{tabular}


Table 5a: Annuity choice and SSP80 - probit estimates

\begin{tabular}{|c|c|c|c|}
\hline Variable & $\begin{array}{l}\text { Baseline } \\
\text { Coefficient } \\
\text { [Marg.eff.] } \\
\text { (Std. Err.) }\end{array}$ & $\begin{array}{l}\text { Augmented } \\
\text { Coefficient } \\
\text { [Marg.eff.] } \\
\text { (Std. Err.) }\end{array}$ & $\begin{array}{l}\text { Restricted } \\
\text { Coefficient } \\
\text { [Marg.eff.] } \\
\text { (Std. Err.) }\end{array}$ \\
\hline SSP80 & $\begin{array}{c}0.060 \text { *** } \\
{[0.024]} \\
(0.020)\end{array}$ & $\begin{array}{c}0.054 * * \\
{[0.022]} \\
(0.022)\end{array}$ & $\begin{array}{c}0.077 \\
{[0.030]} \\
(0.065)\end{array}$ \\
\hline Age & $\begin{array}{c}-0.075 * * \\
{[-0.030]} \\
(0.036)\end{array}$ & $\begin{array}{c}-0.059 \\
{[-0.023]} \\
(0.039)\end{array}$ & $\begin{array}{c}-0.028 \\
{[-0.011]} \\
(0.146)\end{array}$ \\
\hline Age squared & $\begin{array}{c}0.001 * * \\
{[0.001]} \\
(0.000)\end{array}$ & $\begin{array}{c}0.001 * * \\
{[0.001]} \\
(0.000)\end{array}$ & $\begin{array}{c}0.001 \\
{[0.001]} \\
(0.001)\end{array}$ \\
\hline Female & $\begin{array}{c}-0.221 * * \\
{[-0.088]} \\
(0.094)\end{array}$ & $\begin{array}{c}-0.246 * * \\
{[-0.098]} \\
(0.102)\end{array}$ & $\begin{array}{c}-0.172 \\
{[-0.068]} \\
(0.342)\end{array}$ \\
\hline Other pension arrangements & $\begin{array}{c}-0.151 \\
{[-0.060]} \\
(0.094)\end{array}$ & $\begin{array}{c}-0.189 * \\
{[-0.075]} \\
(0.101)\end{array}$ & $\begin{array}{c}0.007 \\
{[0.003]} \\
(0.329)\end{array}$ \\
\hline Bequest & & $\begin{array}{l}-0.002 \\
{[0.029]} \\
(0.001)\end{array}$ & $\begin{array}{c}-0.013 * * \\
{[-0.005]} \\
(0.006)\end{array}$ \\
\hline Constant & $\begin{array}{c}1.110 \\
(0.805)\end{array}$ & $\begin{array}{c}0.871 \\
(0.883) \\
\end{array}$ & $\begin{array}{c}0.739 \\
(3.356)\end{array}$ \\
\hline $\begin{array}{l}\text { Log-likelihood } \\
\text { Pseudo } \mathrm{R}^{2} \\
\text { N.Obs. } \\
\text { Minimum annuity at age }\end{array}$ & $\begin{array}{c}-537.285 \\
0.028 \\
799 \\
38\end{array}$ & $\begin{array}{c}-471.324 \\
0.034 \\
705 \\
35\end{array}$ & $\begin{array}{c}-47.878 \\
0.167 \\
76 \\
24\end{array}$ \\
\hline \multicolumn{4}{|c|}{$\begin{array}{l}\text { The dependent variable is the annuity choice in the first round } \\
\text { Specification (I) : subsample } 22-64 \text { without bequest motive } \\
\text { Specification (II) : subsample } 22-64 \text { with bequest motive } \\
\text { Specification (III) : subsample } 22-64 \text { restricted to those intending to bequeath } \\
* * * \text { denotes significant at } 1 \text {-percent level } \\
* * \text { denotes significant at } 5 \text {-percent level } \\
* \text { denotes significant at } 10 \text {-percent level }\end{array}$} \\
\hline
\end{tabular}


Table 5b: Annuity choice and SSP80 - probit estimates

\begin{tabular}{|c|c|c|c|}
\hline Variable & $\begin{array}{l}\text { Baseline } \\
\text { Coefficient } \\
\text { [Marg.eff.] } \\
\text { (Std. Err.) }\end{array}$ & $\begin{array}{l}\text { Augmented } \\
\text { Coefficient } \\
\text { [Marg.eff.] } \\
\text { (Std. Err.) }\end{array}$ & $\begin{array}{l}\text { Restricted } \\
\text { Coefficient } \\
\text { [Marg.eff.] } \\
\text { (Std. Err.) }\end{array}$ \\
\hline SSP80 & $\begin{array}{c}0.066 \text { *** } \\
{[0.026]} \\
(0.024)\end{array}$ & $\begin{array}{c}0.053 * * \\
{[0.021]} \\
(0.026)\end{array}$ & $\begin{array}{c}0.113 \\
{[0.044]} \\
(0.073)\end{array}$ \\
\hline Age & $\begin{array}{c}-0.055 * \\
{[-0.034]} \\
(0.047)\end{array}$ & $\begin{array}{c}-0.077 \\
{[-0.031]} \\
(0.051)\end{array}$ & $\begin{array}{c}0.016 \\
{[0.001]} \\
(0.193)\end{array}$ \\
\hline Age squared & $\begin{array}{c}0.001 * * \\
{[0.001]} \\
(0.000)\end{array}$ & $\begin{array}{l}0.001 * \\
{[0.001]} \\
(0.000)\end{array}$ & $\begin{array}{c}0.001 \\
{[0.0001]} \\
(0.001)\end{array}$ \\
\hline Female & $\begin{array}{c}-0.304 * * * \\
{[-0.121]} \\
(0.114)\end{array}$ & $\begin{array}{c}-0.345 * * * \\
{[-0.137]} \\
(0.122)\end{array}$ & $\begin{array}{c}-0.437 \\
{[-0.172]} \\
(0.426)\end{array}$ \\
\hline Life policies & $\begin{array}{c}-0.274 * \\
{[-0.109]} \\
(0.165)\end{array}$ & $\begin{array}{c}-0.319 * \\
{[-0.127]} \\
(0.176)\end{array}$ & $\begin{array}{c}0.806 \\
{[-0.310]} \\
(0.594)\end{array}$ \\
\hline Bequest & & $\begin{array}{c}-0.002 \\
{[-0.001]} \\
(0.002)\end{array}$ & $\begin{array}{c}-0.016 * * \\
{[-0.006]} \\
(0.007)\end{array}$ \\
\hline Constant & $\begin{array}{c}1.316 \\
(1.043)\end{array}$ & $\begin{array}{c}1.299 \\
(1.149)\end{array}$ & $\begin{array}{l}-0.173 \\
(4.379)\end{array}$ \\
\hline $\begin{array}{l}\text { Log-likelihood } \\
\text { Pseudo } \mathrm{R}^{2} \\
\text { N.Obs. } \\
\text { Minimum annuity at age }\end{array}$ & $\begin{array}{c}-376.502 \\
0.034 \\
563 \\
39\end{array}$ & $\begin{array}{c}-334.418 \\
0.039 \\
503 \\
37\end{array}$ & $\begin{array}{c}-31.494 \\
0.169 \\
55 \\
-\end{array}$ \\
\hline \multicolumn{4}{|c|}{$\begin{array}{l}\text { The dependent variable is the annuity choice in the first round } \\
\text { Specification (I) : subsample } 22-64 \text { without bequest motive } \\
\text { Specification (II) : subsample } 22-64 \text { with bequest motive } \\
\text { Specification (III) : subsample } 22-64 \text { restricted to those intending to bequeath } \\
* * * \text { denotes significant at } 1 \text {-percent level } \\
\text { ** denotes significant at } 5 \text {-percent level } \\
* \text { denotes significant at } 10 \text {-percent level }\end{array}$} \\
\hline
\end{tabular}


Table 6: Annuity choice, age and SSPs - probit estimates

\begin{tabular}{|c|c|c|c|c|c|c|}
\hline \multirow[t]{4}{*}{ Variable } & \multicolumn{3}{|c|}{ Baseline - Aged 49-64 } & \multicolumn{3}{|c|}{ Baseline - Aged 55-64 } \\
\hline & Coefficient & Coefficient & Coefficient & Coefficient & Coefficient & Coefficient \\
\hline & [Marg.eff.] & [Marg.eff.] & [Marg.eff.] & [Marg.eff.] & [Marg.eff.] & [Marg.eff.] \\
\hline & (Std. Err.) & (Std. Err.) & (Std. Err.) & (Std. Err.) & (Std. Err.) & (Std. Err.) \\
\hline \multirow[t]{3}{*}{ SSP75 } & & $0.079^{* *}$ & & & $0.039 * *$ & \\
\hline & & {$[0.030]$} & & & {$[0.015]$} & \\
\hline & & $(0.038)$ & & & $(0.049)$ & \\
\hline \multirow[t]{3}{*}{ SSP80 } & & & $0.102 * * *$ & & & $0.081 * *$ \\
\hline & & & {$[0.039]$} & & & {$[0.030]$} \\
\hline & & & $(0.030)$ & & & $(0.038)$ \\
\hline \multirow[t]{3}{*}{ Age } & 0.149 & 0.160 & 0.176 & -1.122 & -1.017 & -0.732 \\
\hline & {$[0.057]$} & {$[0.061]$} & {$[0.067]$} & {$[-0.422]$} & {$[-0.383]$} & {$[-0.275]$} \\
\hline & $(0.507)$ & $(0.508)$ & $(0.510)$ & $(1.575)$ & $(1.582)$ & $(1.590)$ \\
\hline \multirow[t]{3}{*}{ Age squared } & -0.001 & -0.001 & -0.001 & 0.009 & 0.009 & 0.006 \\
\hline & {$[-0.001]$} & {$[-0.001]$} & {$[-0.001]$} & {$[0.004]$} & {$[0.003]$} & {$[0.002]$} \\
\hline & $(0.004)$ & $(0.004)$ & $(0.005)$ & $(0.013)$ & $(0.013)$ & $(0.013)$ \\
\hline \multirow[t]{3}{*}{ Female } & $-0.277 *$ & $-0.274 *$ & $-0.303 *$ & -0.096 & -0.093 & -0.107 \\
\hline & {$[-0.107]$} & {$[-0.106]$} & {$[-0.116]$} & {$[-0.036]$} & {$[-0.035]$} & {$[-0.040]$} \\
\hline & $(0.156)$ & $(0.157)$ & $(0.159)$ & $(0.197)$ & $(0.197)$ & $(0.199)$ \\
\hline \multirow{3}{*}{$\begin{array}{l}\text { Other } \\
\text { pension arr. }\end{array}$} & -0.176 & -0.226 & -0.219 & -0.142 & -0.167 & -0.180 \\
\hline & {$[-0.067]$} & {$[-0.086]$} & {$[-0.084]$} & {$[-0.054]$} & {$[-0.063]$} & {$[-0.068]$} \\
\hline & $(0.156)$ & $(0.159)$ & $(0.159)$ & $(0.201)$ & $(0.204)$ & $(0.204)$ \\
\hline \multirow[t]{2}{*}{ Constant } & -4.311 & -4.989 & -5.414 & 33.479 & 30.204 & 21.705 \\
\hline & $(14.298)$ & $(14.325)$ & $(14.395)$ & $(46.829)$ & $(47.066)$ & $(47.314)$ \\
\hline Log-likelihood & -208.169 & -206.045 & -202.485 & -128.257 & -127.945 & -126.020 \\
\hline Pseudo $\mathrm{R}^{2}$ & 0.012 & 0.022 & 0.039 & 0.005 & 0.007 & 0.022 \\
\hline N.Obs. & 315 & 315 & 315 & 196 & 196 & 196 \\
\hline $\begin{array}{l}\text { Max/min. } \\
\text { annuity at age }\end{array}$ & - & $63(\mathrm{M})$ & $62(\mathrm{M})$ & $59(\mathrm{~m})$ & $59(\mathrm{~m})$ & $59(\mathrm{~m})$ \\
\hline \multicolumn{7}{|c|}{$\begin{array}{l}\text { The dependent variable is the annuity choice in the first round } \\
* * * \text { denotes significant at } 1 \text {-percent level } \\
* * \text { denotes significant at } 5 \text {-percent level } \\
* \text { denotes significant at } 10 \text {-percent level }\end{array}$} \\
\hline
\end{tabular}




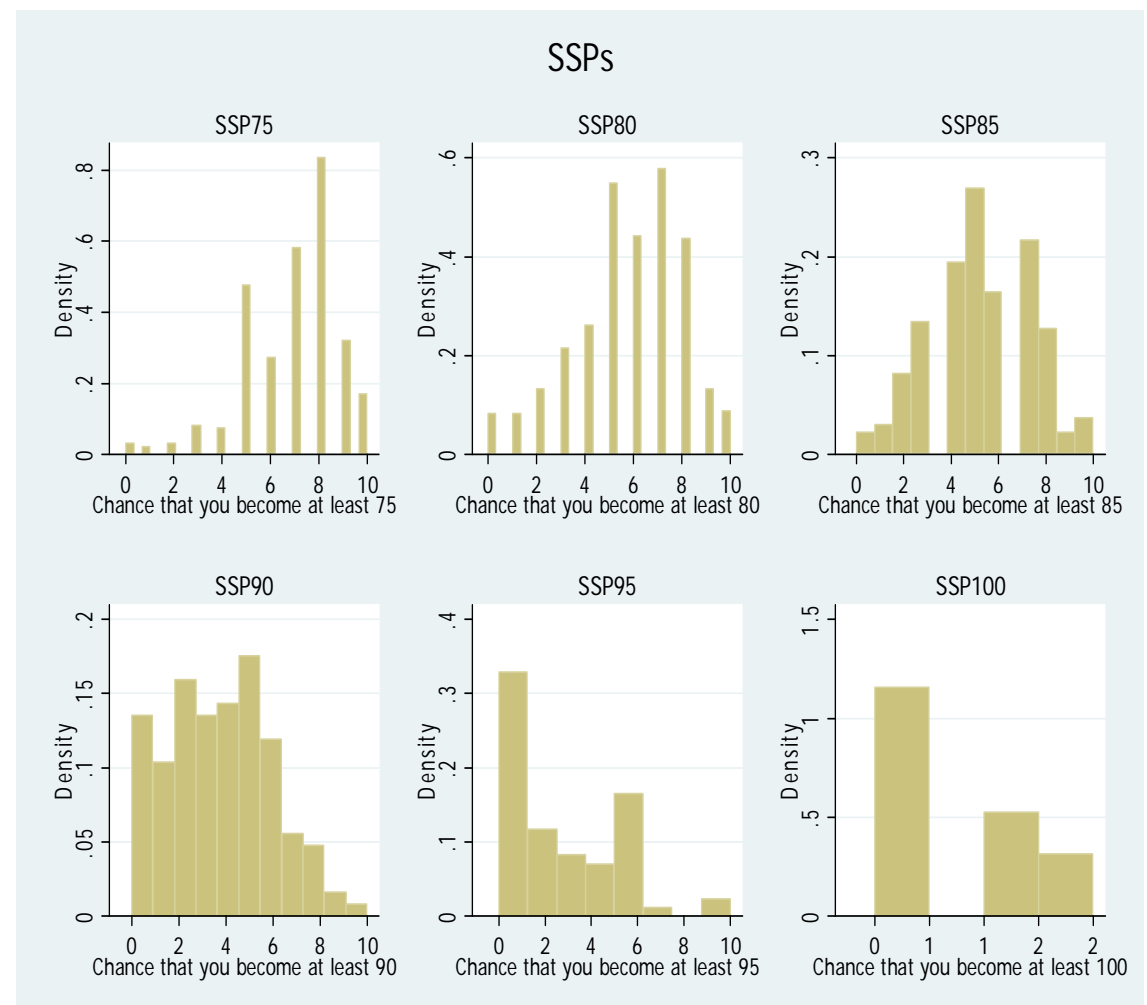

Figure 1: Distributions of the SSPs.

Please indicate your answer on a scale of 0 to 10, where 0 means "no chance at all" and 10 means "absolutely certain".

SSPXX How likely is it that you will attain (at least) the age of XX?

SSP75 is presented to people aged 16 thru 64

SSP80 is presented to people aged 16 thr $\mathrm{u}^{3} 69$

SSP85 is presented to people aged 65 thru 75

SSP90 is presented to people aged 70 thru 80

SSP95 is presented to people aged 75 thru 85

SSP100 is presented to people aged 80 thru 90 


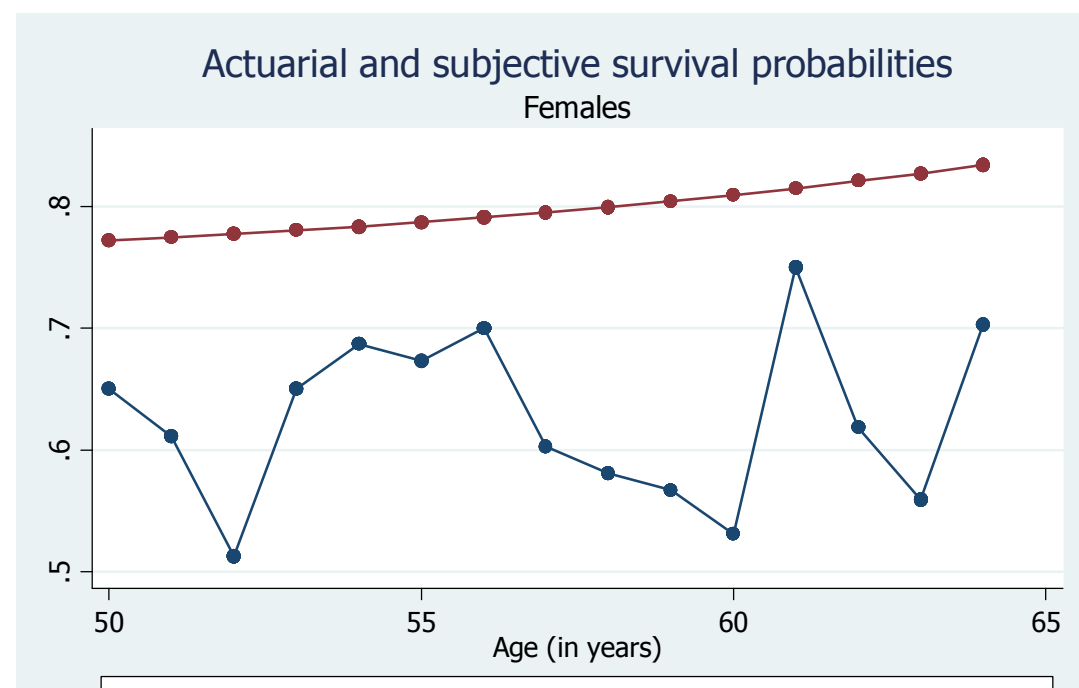

$\longrightarrow$ Subjective survival probability $\longrightarrow$ Actuarial survival probability

Sources: DHS 2005 for subjective survival probabilities; CBS for actuarial survival probabilities

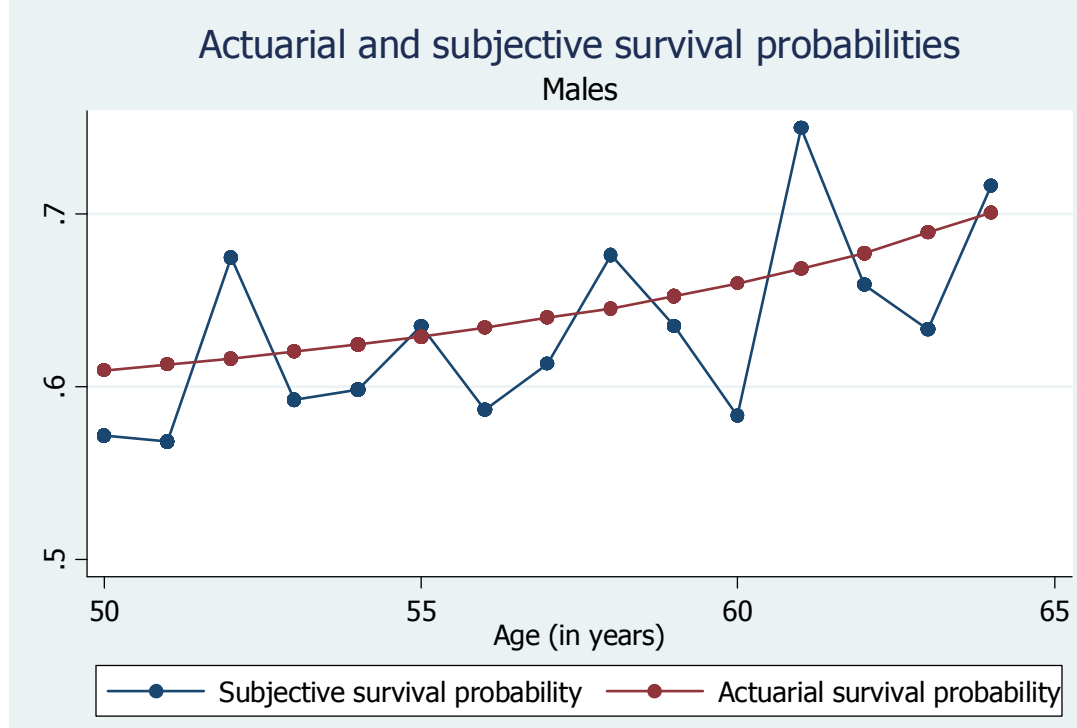

Sources: DHS 2005 for subjective survival probabilities; CBS for actuarial survival probabilities

Figure 2: Survival probabilities to reach 75 years - Actuarial vs. subjective. 


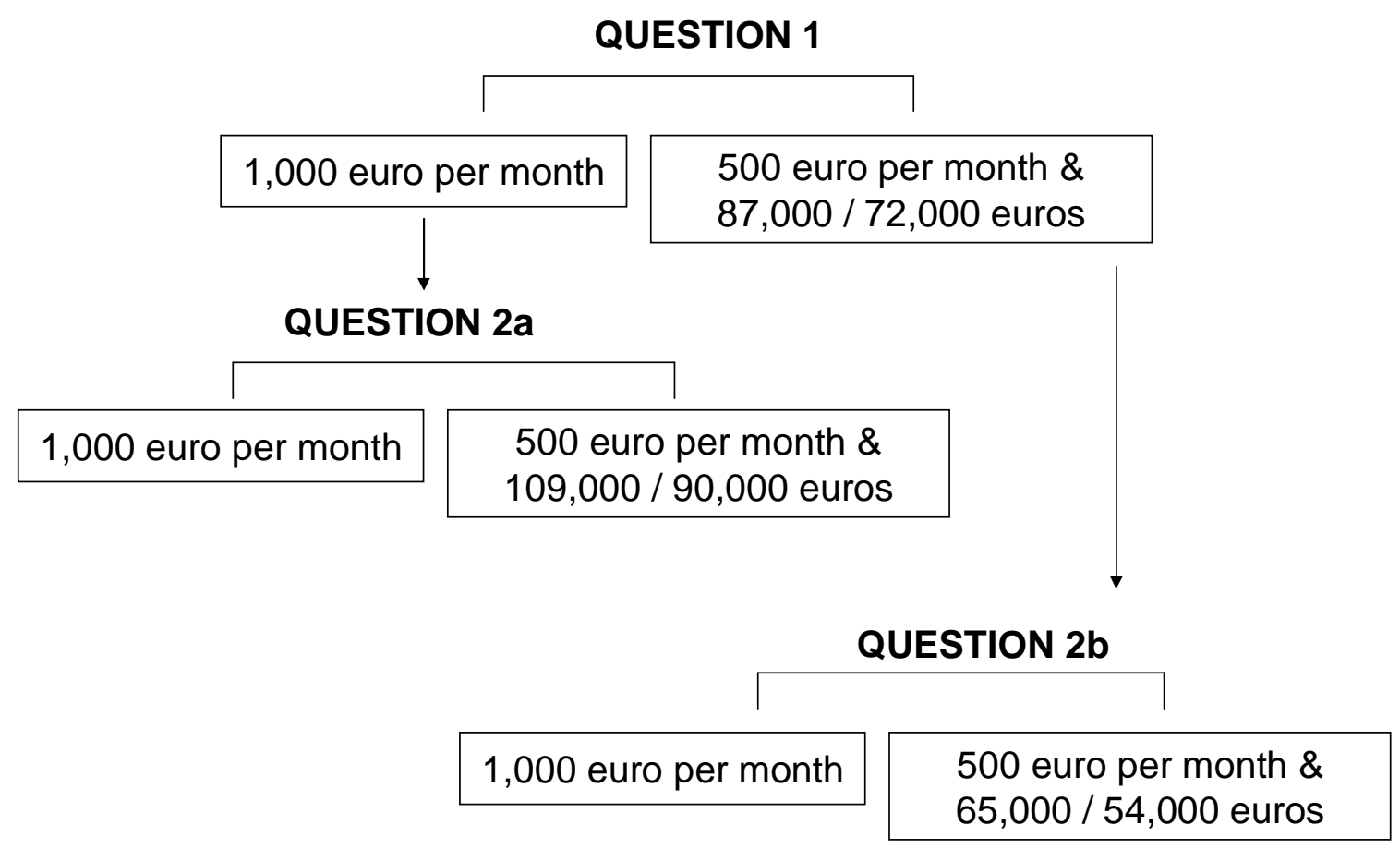

Figure 3: Choice between annuity and (partial) lump sum payment.

Question 1 is asked to all respondents in the sample, irrespective of their working status and for all ages. At this stage, the respondents are given a fair deal. The lump sum payment is computed to be actuarially fair and thus the amount differs by gender: Males are confronted with a payment of 87,000 euros, females with 72,000 euros. Depending on the answer given to this question, the respondents are asked a follow-up question. Question $2 a$ is given to the individuals who had preferred the annuity in the first round: the lump sum payments is made more attractive to them. Question $2 b$ is given to the individuals who had preferred the lump sum payment in the first round: the lump sum payments is made less attractive to them. 


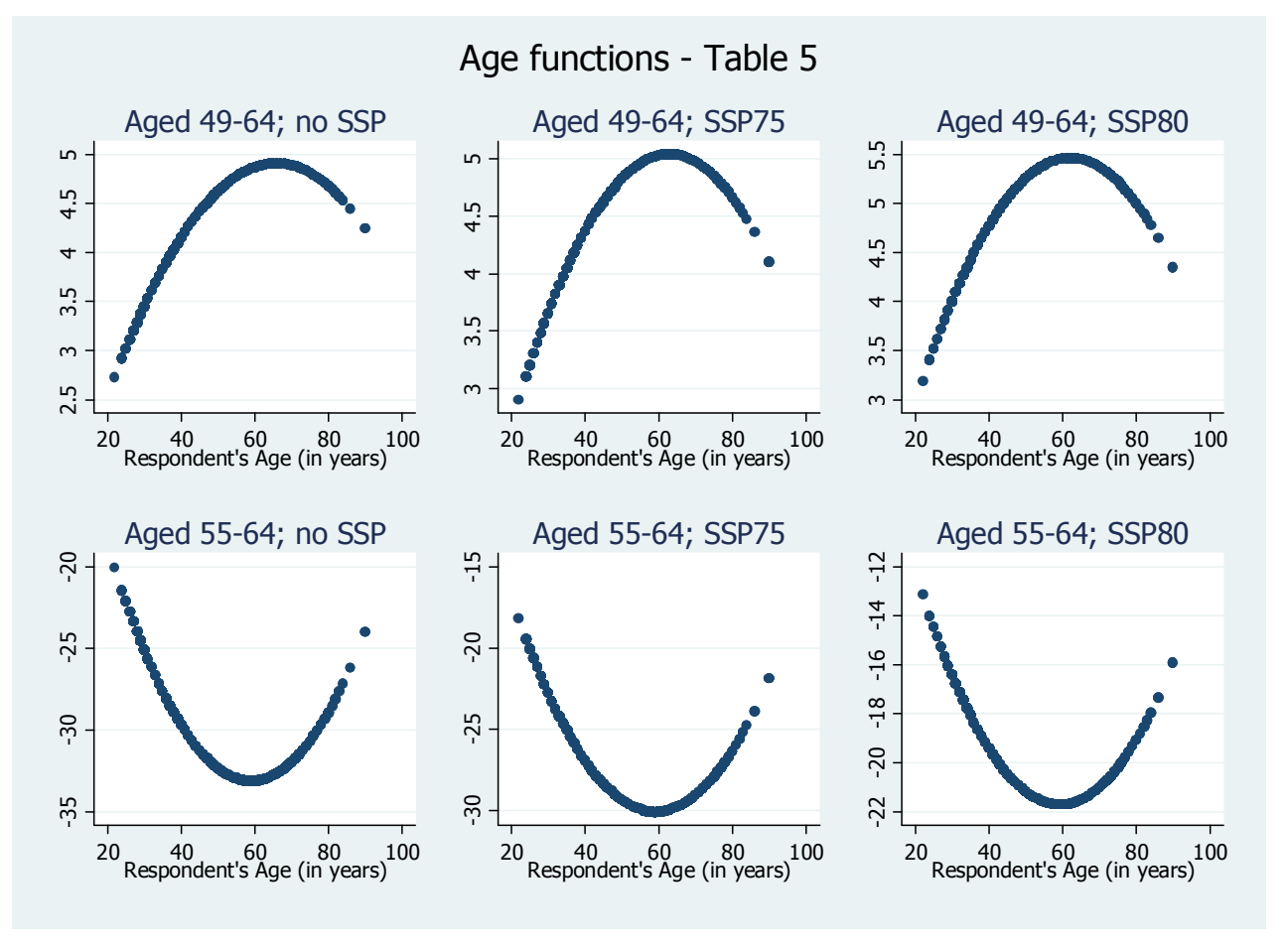

Figure 4: Age functions associated to the regressions in Table 5. 